\title{
Macroeconomic Variables Analysis in Ukraine: An Empirical Approach with Cointegration Method
}

\author{
${ }^{1}$ Nikolaos Dritsakis and ${ }^{2}$ Katerina Gialetaki \\ ${ }^{1}$ Department of Applied Informatics, University of Macedonia \\ Egnatia 156, 54006, Thessaloniki, Greece \\ ${ }^{2}$ Department of Tourism Administration, Technological Education Institute, Amfissa, Greece
}

\begin{abstract}
This study investigates the relationship among exports, economic growth, investments and employment in a former country of the Soviet Union such as Ukraine. The purpose of this study was to examine the long-run relationship between these variables using quarterly data for the period 1991:I2000:IV and applying the cointegration analysis as suggested by Johansen and Juselious. Then a multivariate autoregressive vector model (VAR) is used to estimate the short-run and the long-run relationships of variations of this model. The results suggested that export growth in combination with the increase of investments and employment have a positive effect on Ukraine's economic growth.
\end{abstract}

Key words: Macroeconomic Variables, Cointegration, Ukraine

\section{INTRODUCTION}

Ukraine will complete the thirteenth anniversary of its independence on $24^{\text {th }}$ August 2004. Early forecasts of its disintegration because of the regional, ethnic, and language conflicts proved to be futile. Indeed, the relations among Ukrainians and other ethnic minorities are very close. The country's economy was stabilized to a significant degree by the financial fund of the International Monetary Fund and by the application of government policy, which has adopted a new program of economic reforms.

Ukraine has signed treaties of friendship with all of its neighbors, including its former imperial master, the Russian Federation, and settled all outstanding boundary disputes with them. Emerging from the remnants of a large Eurasian Empire, Ukraine signalled a "European choice" in its foreign policy early on and has played an active role in NATO's Partnership for Peace (PfP) and in peacekeeping operations in Southeastern Europe. Ukraine seeks integration into Europe and cooperation with Russia, http://www.csis.org/europe/pubs/UkraineInEurope.pdf. ${ }^{[1]}$.

The ultimate goal of the common cooperation between EU and Ukraine is related to the respect of democratic principles, the protection of human rights and the transition process to a market economy. For this reason, the Partnership and Cooperation Agreement (PCA) and the EU's Common Strategy (CS) should be applied between Ukraine and EU in determining the political and strategic importance of their relations. The PCA is an important instrument in harmonizing Ukraine's legal framework with the single European market and the World Trade Organization (WTO) system. The PCA also provides trade liberalization, allows free turnover of goods, services, labor and capital, strengthens the economic development and leads to the investment growth.
The European Union's Common Strategy adopted in 1999 as a new instrument, under the Common Foreign and Security Policy. It aims to develop a strategic partnership between the EU and Ukraine on the basis of the PCA, since it acknowledges its convergence to the EU. This common strategy sets three principal objectives:

- "Economic" and democratic transition process in Ukraine

- "Meeting" of common challenges on the European continent such as stability and safety in Europe, environment, energy and nuclear disarmament

- "Strengthening" of the cooperation between Ukraine and EU in the context of enlargement integration into the European and world economy.

Ukraine, the second largest country in Europe in terms of surface area, will become an even more crucial neighbor and partner for the EU after enlargement. As Ukraine's immediate neighbors, the European Union has demonstrated a particular interest in this stable independent state in political and economic level.

Ukraine continues its democratic development and accelerates the transition process to a free market economy. Also, It is an attraction pole for the development of commercial relations with the EU and its member states, for the growth of exporting trade and the free turnover of goods and the installation of multinational enterprises, which affect the economic and political status of the country.

The available energy resources and the anxiety for of the existence of nuclear weapons led to the growth of an international competitive market, where different political and economic interests will dominate. The illegal immigration, the disarmament of nuclear weapons and the fight against organized crime and 
terrorism are the most crucial issues in the transition process to the EU.

The reduction of inflation and the adoption of a new stable currency, the hryvnya, which introduced in 1996, conduced to the economic development of the country. The Ukranian government had to start from scratch to build a system of public administration and to reform the judiciary sector on the basis of the accession process to the European Union, http://europa.eu.int/comm/external_relations/ukraine/cs p/02 06en.pdf ${ }^{[2]}$.

Investment is projected to be an important factor of sustainable long-term growth in the next 5 years. In real terms, gross investment grew at $14.4 \%$ in 2000 and $17.2 \%$ in 2001 . Total investment remained heavily concentrated in the traditional industrial areas of the country. Two thirds of the investment realized in 2001 were financed exclusively by enterprise funds. The second most important source of the investment financing was constituted by bank credits, the share of which has grown considerably over the last three years and reached $14 \%$ of the total in 2002.

This upward trend of investment flows from the introduction of market principals in the agricultural sector and the reduction of barters in economic transactions. In line with recent levels, about $11 \%$ of investment was financed by the state budget. In 2002 an improvement of investment climate in the country was noted and the most important factors led to this result attributed to the stability of the exchange rate of the hrvynia and the rapid growth of the long-run bank credits.

However, The investment environment in Ukraine would become more attractive if the government should:

- "Continue" the privatization of public enterprises in transparent and competitive ways

- "Strengthen" the capital adequacy and Central Bank supervision of the banking system. Strong and healthy commercial banks will permit to narrow interest spreads and fees, and thus promotes further investment and growth

- "Promote" greater transparency in the public decision-making process

- "Implement" the tax reforms simplifying the tax system and reducing rates.

The efforts of a Ukranian government to speed up the tax reforms consist of an important step for the improvement of the investment environment. The introduction of the new Tax Code could ensure economic equilibrium in order to preserve macroeconomic stability, which is sensitive to domestic and external shocks. The gross fixed capital formation grew up by $17.2 \%$ because of the bank credit growth by $46 \%$ in 2001, http://www.oecd.org/pdf/M00027000/ M00027582.pdf ${ }^{[3]}$.
According to the State Committee of Statistics of Ukraine the growth rate of merchandise exports was $11.6 \%$, while exports increased by $13 \%$ respectively. In January 2002 economic growth and industrial production decelerated to $3.2 \%$ and $1.7 \%$ respectively. Exports constitute about 57\% of GDP in 2001 and consisted the main source of foreign exchange in Ukraine. The most urgent step for Ukraine is to become a member of World Trade Organization (WTO).

The ultimate goal of the National Bank is to maintain the inflation rate in low levels. Indeed, the consumer price index came down from $25.8 \%$ in 2000 to $6.1 \%$ in 2001, while in January 2002 was $5.6 \%$. The public deficit was estimated by $0.5 \%$ of GDP. The goal of a zero budget deficit was almost achieved. Despite the shortage of capital inflows, the current public surplus is efficient to cover the public debt of the country, $\quad$ http://www.oecd.org/pdf/M00026000/ M00026727.pdf ${ }^{[4]}$.

The high level of unemployment and lower standard of living are the main characteristics of the Ukranian economy during the last years. The problem of unemployment came up as a result of economic crises, which aroused after the breakdown of the Soviet Union. If in 1992 the number of the registered unemployed was 70 thousand, in 1997 it became 5 times more.

The level of employment in Ukraine is one of the lowest among other European countries. The average annual rate of the employed for the period 1990-1999 in the industrial sector was $56,4 \%$, in agriculture sector was $98 \%$ and in manufacturing was $41,7 \%$. The level of employment is related to the level of education, while it is followed by the dramatic decline in production and in the level of real wages. In 1999 the employment rate of the total population was $54,7 \%$ and the unemployment rate was $12 \%$ respectively. In the labor market, which is characterized by the correlation between supply and demand and the prevailing financial system, young specialists with the higher educational level and professional skills should be employed, http:// www.aueb.gr/espe2001/pdf/Gerasymenko\%20S.,\%20 Gerasymenko\%20O. PDF.

Theoretical and Empirical Approaches: There is a wide body of literature analyzing the theoretical relation between exports and economic growth. According to this literature there are two other intermediate variables, which affect this relation. Clearly, since exports are a component of GDP, export growth contributes directly to GDP growth. However, there are important indirect factors, which affect this relationship between exports and economic growth. Exports relax binding foreign exchange constraints and allow increases in imported capital goods ${ }^{[1-5]}$. Also, Exports allow poor countries with narrow domestic market to benefit from economies of scale ${ }^{[6]}$. 
Furthermore, exports conduce to improved efficiency in resource allocation and lead to better utilization of capital ${ }^{[7-9]}$. Moreover, Exports facilitate the diffusion of technology knowledge through learning -by -doing ${ }^{[10]}$.

Early empirical tests of the export-led growth hypothesis adopted an augmented production-function approach, in which exports are included in addition to the traditional inputs of capital and labor $\left.{ }^{[7,} 11,12\right]$. In these studies researchers resulted in the conclusion that there is a contemporary correlation between exports and economic growth ${ }^{[7,11,13,17]}$.

Exports affect positively the components of economic growth such as investments and labor ${ }^{[18-20]}$. Furthermore, exports expansion increases productivity by offering greater economies of scale ${ }^{[6,21,22]}$, brings about higher quality products because of the exporter's exposure to international consumption patterns ${ }^{[23]}$. Also Exports expansion leads a firm to over invest in new technology as a strategy for release to a larger scale of output, increasing the rate of capital formation and technological change ${ }^{[24,}{ }^{25]}$. An export-oriented approach in labor surplus economy permits the rapid growth of employment and real wages ${ }^{[23]}$.

The methodology proposed by Granger ${ }^{[26]}$ and $\mathrm{Sims}^{[27]}$ for causality test of the relationship between exports and economic growth is based on the estimation of bi-varied relationships between the two variables. These tests are designed to capture exclusively the short run dynamics between the two variables. The recent development of cointegration analysis allowed researchers to test for the existence of this long-run equilibrium relationship between exports and output.

In this study a multivariate Vector Auto Regressive model (VAR) has been used, in which in addition to exports and economic growth, investment and employment are included. The focus on this multivariate dynamic model permit us to investigate the effects of exports on these two extra variables and to identify the factors through which economic development affects export growth.

The multivariate VAR approach presupposes the possible existence of short-term relations between exports and the other variables, but it allows us to study the longrun effects of exports on the other variables as well.

Since the previous literature has largely ignored the dynamic interactions between exports and these two extra variables, investment and employment, it could be noted that the incorporation of such dynamic interaction is a very important element of this approach. Consequently, exports can affect economic growth directly or indirectly through their effects on investment and employment and in turn, economic growth should affect exports.

Data-Specification Model: A VAR approach is adopted in this study to estimate the effects of export growth on the growth of domestic variables. The use of this methodology allows us to identify long-term cumulative effects by taking into account the dynamic feedback between exports and the domestic variables $^{[18]}$.

In time-series analysis appropriate differencing is important because most estimation algorithms fail when the time series are nonstationary. In addition, there may be efficiency gains from differencing. For small samples, the distributions of the estimates can be improved by estimating the VAR model in differences ${ }^{[28]}$. Since there are only 44 observations in each time series in our sample, we use the first differences of each series in our estimation. In addition to the above econometric considerations, the use of first differences facilitates our interpretations of the results, since the first differences of the logarithms of the original variables represent the growth rate of the original variables.

For cointegration analysis between exports, investments, economic development and employment, we use the following multivariable VAR model:

$\mathrm{EXP}=\mathrm{f}(\mathrm{GDP}, \mathrm{INV}, \mathrm{EMP})$

Where:

EXP are the experts

GDP is the economic development

INV is the investment

EMP is the employment

The economic development variable is measured by the real GDP (nominal GDP adjusted by the GDP deflator). The Investment Variable (INV) is measured by the gross fixed capital adjusted by the GDP deflator. The export variable is measured by the real export revenue and is obtained by adjusting the nominal export value of an export price index from the International Financial Statistics (IFS). The employment variable EMP is estimated by the number of employed people. The data that used in this analysis are quarterly, cover the period 1991: I -2001:IV regards 1996 as a base year and derived from the database of OECD (Business Sector Data Base).

All data are expressed by logarithms in order to include the proliferative effect of time series and are symbolized by the letter $\mathrm{L}$ preceding each variable name. If these variables share a common stochastic trend and their first differences are stationary, then they can be cointegrated. Economic theory scarcely provides some guidance for which variables appear to have a stochastic trend and when these trends are common among the examined variables as well. For the analysis of the multivariate time series that include stochastic trends, the augmented Dickey-Fuller unit root test is used for the estimation of individual time series, with the intention to provide evidence for when the variables are integrated. The unit root test is followed by the multivariate cointegration analysis. 
Table 1: DF/ADF Unit Root Tests

\begin{tabular}{llllllr}
\hline Variables $\left(\mathrm{X}_{\mathrm{t}}\right)$ & \multicolumn{3}{c}{ In levels } & \multicolumn{2}{c}{$1^{\text {nd }}$ differences } \\
\hline & Lag & $\begin{array}{l}\text { Test statistic } \\
(\mathrm{DF} / \mathrm{ADF})^{*}\end{array}$ & LM(4)** & Lag & $\begin{array}{l}\text { Test statistic } \\
(\mathrm{DF} / \mathrm{ADF})^{*}\end{array}$ & LM(4)** \\
\hline LEXP & 2 & -3.4205 & $2.3171[0.269]$ & 2 & -3.6947 & $0.2203[0.629]$ \\
LGDP & 4 & -2.8349 & $0.0992[0.758]$ & 4 & -3.9926 & $3.2497[0.121]$ \\
LINV & 4 & -3.2302 & $0.3102[0.624]$ & 4 & -4.1154 & $0.3281[0.642]$ \\
LEMP & 0 & -2.9344 & $0.2900[0.674]$ & 1 & -5.7612 & $1.4091[0.267]$ \\
\hline
\end{tabular}

*Critical value: -3.5279 , **The numbers in brackets show the levels of significance (for serial correlation test)

Table 2: Johansen and Juselious Cointegration Tests

Variables LEXP, LGDP, LINV, LEMP

The maximum lags in VAR $=3$

\begin{tabular}{lllll}
\hline Eigenvalues & & & Critical values & $90 \%$ \\
\hline Null & Alternative & Eigenvalue & $95 \%$ & 21.5800 \\
$\mathrm{r}=0$ & $\mathrm{r}=1$ & 32.0895 & 23.9200 & 15.5700 \\
$\mathrm{r}=1$ & $\mathrm{r}=2$ & 11.8686 & \multicolumn{2}{c}{ Critical values } \\
\hline Trace statistic & & & $95 \%$ & $90 \%$ \\
\hline Null & Alternative & Eigenvalue & 39.8100 & 36.6900 \\
\hline $\mathrm{r}=0$ & $\mathrm{r}>0$ & 46.4426 & 24.0500 & 21.4600 \\
$\mathrm{r} \leq 1$ & $\mathrm{r}>1$ & 14.3531 & & \\
\hline
\end{tabular}

Table 3: Error Correction Model

$$
\begin{aligned}
& \Delta \mathrm{LEXP}_{\mathrm{t}}=0.037499+0.70939 \Delta \mathrm{LEXP}_{\mathrm{t}-1}+0.32217 \Delta \mathrm{LGDP}_{\mathrm{t}-1}+0.29027 \Delta \mathrm{LGDP}_{\mathrm{t}-2} \\
& \begin{array}{llll}
(1.7978) & (2.8109) & (2.9465) & (1.8480)
\end{array} \\
& {[0.082] \quad[0.008] \quad[0.006] \quad[0.074]} \\
& +0.55090 \Delta \text { LINV }_{\mathrm{t}-1}+0.42047 \Delta \text { LEMP }_{\mathrm{t}-2}-0.13167 \mathrm{u}_{\mathrm{t}-1} \\
& \text { (2.6479) (1.6105) (-1.0742) } \\
& \text { [0.006] [0.081] [0.291] } \\
& \overline{\mathrm{R}}^{2}=0.51 \quad \mathrm{~F}(6,34)=5.6005 \quad \mathrm{DW}=1.7259 \\
& \text { A: } X^{2[1]}=2.1597 \quad \text { B: } X^{2[1]}=0.48957 \\
& \mathrm{C}: \mathrm{X}^{2[2]}=1.7676 \quad \mathrm{D}: \mathrm{X}^{2[1]}=\begin{array}{l}
{[0.484]} \\
2.3628
\end{array} \\
& \text { [0.413] }
\end{aligned}
$$

Notes

$\Delta$ : Denotes the first differences of the variables.

$\bar{R}^{2}=$ Coefficient of multiple determination adjusted for the degrees of freedom (d.f).

$\mathrm{DW}=$ Durbin-Watson statistic.

$\mathrm{F}(\mathrm{n}, \mathrm{m})=$ F-statistic with $\mathrm{n}, \mathrm{m}$ d.f respectively

A: $X^{2}(n)$ Lagrange multiplier test of residual serial correlation, following $x^{2}$ distribution with $n$ d.f.

B: $X^{2}(n)$ Ramsey's Reset test for the functional form of the model, following $x^{2}$ distribution with $n$ d.f.

C: $\mathrm{X}^{2}(\mathrm{n})$ Normality test based on a test of skewness and kurtosis of residuals, following $\mathrm{x}^{2}$ distribution with $\mathrm{n}$ d.f.

D: $\mathrm{X}^{2}(\mathrm{n})$ Heteroscedasticity test, following $\mathrm{x}^{2}$ distribution with $\mathrm{n}$ d.f.

$(\mathrm{r})$ We denote the $\mathrm{t}$-ratio of the corresponding estimated regression coefficient.

[ ] = We denote probe. Levels.

Unit Root Test: The cointegration test among the variables that are used in the above model requires previously the test for the existence of unit root for each variable and specificity, for economic development, exports, investment and employment, using the augmented Dickey-Fuller $(\mathrm{ADF})^{[29]}$ test on the following regression:

$\Delta \mathrm{X}_{\mathrm{t}}=\delta_{\mathrm{o}}+\delta_{1 \mathrm{t}}+\delta_{2} \mathrm{Xt}-1+\sum_{\mathrm{i}=1}^{\mathrm{k}} \alpha_{\mathrm{i}} \Delta \mathrm{X}_{\mathrm{t}-\mathrm{i}}+\mathrm{u}_{\mathrm{t}}$

The ADF regression tests for the existence of unit root of $\mathrm{Xt}$, namely in the logarithm of all model variables at time $\mathrm{t}$. The variable $\Delta \mathrm{Xt}-1$ expresses the first differences with $\mathrm{k}$ lags and final $\mathrm{u}_{\mathrm{t}}$ is the variable that adjusts the errors of autocorrelation. The coefficients $\delta o, \delta 1, \delta 2$ and $\alpha$ are being estimated. The null and the alternative hypothesis for the existence of a unit root in variable cost is

$\mathrm{H}_{\mathrm{o}}: \delta_{2}=0 \quad \mathrm{H}_{\varepsilon}: \delta_{2}<0$

The results of these tests appear in Table 1. The minimum values of the Akaike (AIC) ${ }^{[30]}$ and Schwartz $(\mathrm{SC})^{[31]}$ statistics have provided the better structure of the ADF equations as well as the relative amount of time lags, under the indication "Lag". As far as the autocorrelation disturbance term test is concerned, the Lagrange Multiplier LM (4) test has been used. The MFIT $4.0^{[32]}$ econometric package that was used for the estimation of ADF test, provides us the simulated critical values.

The results of Table 1 suggest that the null hypothesis of a unit root in the time series cannot be 
rejected at a 5\% level of significance in varying levels. Therefore, no time series appear to be stationary in varying levels. However, when the logarithms of the time series are transformed into their first differences, they become stationary and consequently the related variables can be characterized integrated order one, I (1). Moreover, for all variables the LM (4) test first differences show that there is no correlation in the disturbance terms.

Cointegration and Johansen Test: If the time series (variables) are non-stationary in their levels, they can be integrated with integration of order 1, when their first differences are stationary. These variables can be cointegrated as well, if there are one or more linear combinations among the variables that are stationary. If these variables are being cointegrated, then there is a constant long-run linear relationship among them. Granger ${ }^{[33]}$ argued that 'a test for cointegration can thus be thought of as a pre-test to avoid 'spurious regression situations'.

Since it has been determined that the variables under examination are integrated of order 1 , then the cointegration test is performed. The testing hypothesis is the null of non-cointegration against the alternative that is the existence of cointegration using the Johansen $^{[34]}$ maximum likelihood procedure, Johansen and Juselious ${ }^{[35,36]}$. An autoregressive coefficient is used for the modelling of each variable (that is regarded as endogenous) as a function of all lagged endogenous variables of the model.

Given the fact that in order to apply the Johansen Technique a sufficient number of time lags is required, we have followed the relative procedure, which is based on the calculation LR (Likelihood Ratio) test statistic ${ }^{[27]}$. The results showed that the value $\rho=3$ is the appropriate specification of the above relationship.

The order of $r$ is determined by using the Likelihood Ratio (LR) trace test statistic suggested by Johansen $^{[34]}$ :

$\lambda \operatorname{trace}(\mathrm{q}, \mathrm{n})=-\mathrm{T} \sum_{\mathrm{i}=\mathrm{q}+1}^{\mathrm{k}} \ln \left(1-\hat{\lambda}_{\mathrm{i}}\right)$

for $\mathrm{r}=0,1,2, \ldots \ldots \mathrm{k}-1$,

$\mathrm{T}=$ the number of observations used for estimation

$\hat{\lambda}_{i}=$ is the ith largest estimated eigenvalue.

The critical values for the trace statistic defined by equation (3) are 39.81 and 36.69 for Ho: r=0 and 24.05 and 21.46 for Ho: $r<1$ at the significance level $5 \%$ and $10 \%$, respectively as reported by Osterwald-Lenum ${ }^{[35]}$.

The maximum eigenvalue LR test statistic as suggested by Johansen is:

$\lambda \max (\mathrm{q}, \mathrm{q}+1)=-\mathrm{T} \ln \left(1-\hat{\lambda}_{\mathrm{q}+1}\right)$
The trace statistic either rejects the null hypothesis of no cointegration among the variables $(\mathrm{r}=0)$ or does not reject the null hypothesis that there is one cointegrating relation between the variables ( $\mathrm{r}(1)$.

The results that appear in Table 2 suggest that the number of statistically significant cointegration vectors is equal to 1 and are the following:

$\mathrm{LEXP}=0.76854 \mathrm{LGDP}+1.7021 \mathrm{LINV}+0.93492 \mathrm{LEMP}$ (4.173) (2.949)

The coefficients estimations in equilibrium relationships, which are basically the long-term estimated elasticities relative to export growth, suggest that investments are elastic while economic development and employment are inelastic.

According to the signs of the vector cointegration components and based on the basis of economic theory the above relationships can be used as an error correction mechanism in a VAR model.

VAR Model with an Error Correction Mechanism: After determining that the logarithms of the model variables are cointegrated, we must estimate then a VAR model in which we shall include a Mechanism of Error Correction model (MEC). The error-correction model arose from the long-run cointegration relationship and has the following form:

$\Delta \mathrm{LGDPt}=$ lagged $(\Delta \mathrm{LGDPt}, \Delta \mathrm{LEXPt}, \Delta \mathrm{LINVt}$,
$\Delta \mathrm{LEMPt})+\lambda \mathrm{ut}-1+\mathrm{Vt}$

where, $\Delta$ is reported to all variables first differences ut - $_{1}$ are the estimated residuals from the cointegrated regression (long-run relationship) $-1<\lambda<0$ short-run parameter $V_{t}$ white noise disturbance term

One difficulty confronting a researcher in estimating a VAR model is the appropriate specification of the model. In particular, the researcher has to decide what deterministic components should be included as well as the number of time lags that_should be used. Since arbitrarily chosen specifications of a VAR model are likely to produce unreliable results, we use a data based model selection criterion to specify the VAR model for Ukraine's economy. Among various model selection criteria the one proposed by Schwartz ${ }^{[31]}$, known as Schwartz Bayesian information Criterion (SBC), is shown to outperform other alternatives $^{[38]}$. Therefore, Our specification of the VAR model is based on Schwartz Bayesian information criteria. Schwartz's criterion selected a first order VAR specification with constant and time trend as well.

The final form of the Error-Correction Model was selected according to the approach suggested by Hendry ${ }^{[39]}$. The initial order of the time lag for the model is 2 years, because it is large enough to enclose the system's short-run dynamic. We also apply a number of diagnostic tests on the residuals of the 
model. We apply the Lagrange test (LM) for the possible existence of autocorrelation and heteroscedasticity, the Bera-Jarque (C) normality test and the Ramsey's Reset test for the functional form of the model. The Error Correction Model appears in Table 3.

We do not reject the estimations, which are based on the results of Table 3 according to the statistical and diagnostic tests. The percentage of the total variance of the dependent variable that is described in our model is high enough (51\%). The Error Correction Term is not statistically significant although it has a negative sign, which confirms that there is a problem in the long-run equilibrium relation between the independent and dependent variables in 5\% level of significance, but its relative value $0.13167(-1.0742)$ shows a satisfactory rate of convergence to the equilibrium state per period.

A short-run increase of economic development per $1 \%$ induces an increase of export growth per $0.32 \%$, an increase of investments per $1 \%$ induces an increase in export growth per $0.55 \%$, while an increase of employed per $1 \%$ induces an increase of export growth per $0.42 \%$ (Table 3 ).

\section{CONCLUSION}

This study employs with the relationship between export growth, economic development, investment, and employment in a former country of the Soviet Union, using quarterly data for the period 1991:I-2001IV. The empirical analysis suggested that the variables that determine export growth in Ukraine present a unit root. On this basis the cointegration analysis has been used as suggested by Johansen and Juselious to arise a longrun equilibrium relationship among the examined variables. The results of this analysis show that there is a positive relationship between export growth, investment, employment and economic development. Then an error correction model's methodology was used to estimate the short-run and long-run relationships. The selected vectors gave us the error correction terms, which proved to be statistically insignificant in 5\% level of significance during their introduction in short-run dynamic equations.

The results of positive long-run effects of economic development investments and employment on export growth are consistent with the arguments for positive external effects of these variables in the literature. Greater export opportunities should promote investment not only in the export sector but also in other sectors related to exports. Furthermore, export growth in developing countries such as Ukraine, typically suggests a shift of domestic production towards more labor-intensive commodities with comparative advantages in the world market. The results of Table 3 suggested that investment growth is the most important factor for Ukranian exports as a result of Levine and Renelt's ${ }^{[40]}$ study.
Finally, the effects of economic development on export growth through the employment and investment proved to be positive for Ukraine. This fact emphasizes the role of indirect intermediate variables through economic development affects export growth in this country.

\section{REFERENCES}

1. Mckinnon, R., 1964. Foreign exchange constraint on economic development and efficient aid allocation. Economy. J., 74: 388-409.

2. Chenery, H. and A. Strout, 1966. Foreign assistance and economic development. American economy. Rev.,: 679-733.

3. Voivodas, C., 1973. Exports, Foreign Capital Inflow and Economic Growth. J. Intl. Economy., 3: 337-349.

4. Afxentiou, P. and A. Serletis, 1992. Openness in the Canadian economy 1870-1988. Appl. Economy. Lett., 3: 567-570.

5. Federici, D. and D. Marconi, 2002. On exports and economic growth: The case of Italy. J. Intl. and Econom. Develop., 11: 323-340.

6. Helpman, E. and P. Krugman, 1985. Market Structure and Foreign Trade. Cambridge MA: MIT Press.

7. Balassa, B., 1978. Exports and economic growth: Further evidence. J. Develop. Economy., 5: 181-9.

8. Bhagdati, J. and T. Srinivasan, 1979. Trade Policy and Development. In Dornsbuch and Frenkel (Eds.), International Economic Policy: Theory and Evidence, Baltimore: John Hopkins University Press.

9. Krueger, A., 1980. Trade policy as an input to development. American economy. Rev., 70: 28892.

10. Grossman, G.M. and E. Helpman, 1991. Innovation and Growth in the Global Economy. Cambridge MA: MIT Press.

11. Feder, R., 1982. On exports and economic growth. J. Develop. Economy., 12: 59-73.

12. Anwer, M. and R.K. Sampath, 2000. Exports and economic growth. The Indian Economy. J., 47: 7988.

13. Michaelly, M., 1977. Export and growth: An empirical investigation. J. Develop. Economy., 4: 49-53.

14. Tyler, W.G., 1981. Growth and export expansion in developing countries. J. Develop. Economy., 9: 121-130.

15. Ram, R., 1987. Export and economic growth in developing countries: Evidence from time-series and cross section data. Economy. Develop. Cultural Change, 35: 51-72.

16. Sun, H. and A. Parikh, 1999. Exports and economic growth in China. Working Paper No. 9905, February. 
17. Dritsakis, N., 2004a. Exports, investments and economic development of pre-accession countries of the European Union: An empirical investigation of Bulgaria and Romania. Appl. Econom., 36: 1831-1838.

18. Pereira A. and Z. Xu, 2000. Export growth and domestic performance. Rev. Intl. Econom., 8: 6073.

19. Abdulai, A. and P. Jaquet, 2002. Exports and economic growth: Cointegration and causality evidence for Côte D'Ivoire. African Develop. Rev., 14: 1-17.

20. Dritsakis, N., 2003. Hungarian macroeconomic variables- reflection on causal relationships. Acta Oeconomica, 53: 61-73.

21. Lee, C.H. and B.N. Huang, 2002. The relationship between exports and economic growth in East Asian countries: A multivariate threshold autoregressive approach. J. Economy. Develop., 27: 45-68.

22. Dritsakis, N., 2004b. A causal relationship between inflation and productivity: An empirical approach for Romania. American J. Applied Sci., 1: 121128.

23. Krueger, A., 1985. The experiences and lessons of Asia's super exporters in V. Corbo, A. Krueger, and F. Ossa Export-oriented development strategies: The success of five newly industrializing countries. West view Press, Boulder, CO.

24. Rodrik, D., 1988. Closing the technology gap: Does trade liberalization really help? Cambridge NBER Working Paper no. 2654.

25. Sinha, D. and T. Sinha, 2002. Openness, Investment and Economic Growth in Asia. The Indian Economy. J., 49: 90-95.

26. Granger, C., 1969. Investigating causal relations by econometric models and cross-spectral methods. Econometrica, 37: 424-438.

27. Sims, C., 1980. Macroeconomics ad Reality, Econometrica, 48: 1-48.

28. Hamilton, J.D., 1994. Time Series Analysis. New Jersey: Princeton University Press.
29. Dickey, D.A. and W.A. Fuller, 1979. Distributions of the estimators for autoregressive time series with a unit root. J. American Stat. Assoc., 74: 427-431.

30. Akaike, H., 1973. Information Theory and an Extension of the Maximum Likelihood Principle. In: Petrov, B. and Csaki, F. (Eds) $2^{\text {nd }}$ International Symposium on Information Theory. Budapest: Akademiai Kiado.

31. Schwartz, R., 1978. Estimating the dimension of a model. Ann. Stat., 6: 461-464.

32. MFIT 4.0, 1997. Quantitative Micro Software, Interactive Econometric Analysis. Oxford University Press.

33. Granger, C., 1986. Developments in the study of cointegrated economic variables. Oxford Bull. Economy. Stat., 48: 213-228.

34. Johansen, S., 1988. Statistical analysis of cointegration vectors. J. Economic Dynamics and Control, 12: 231-254.

35. Johansen, S. and K. Juselious, 1990. Maximum likelihood estimation and inference on cointegration with applications to the demand for the money. Oxford Bull. Economy. Stat., 52: 169210 .

36. Johansen, S. and K. Juselius, 1992. Testing structural hypotheses in a multivariate cointegration analysis at the purchasing power parity and the uncovered interest parity for the UK. J. Economy., 53: 211-244.

37. Osterwald-Lenum, M., 1992. A note with quantiles of the asymptotic distribution of the maximum likelihood cointegration rank test statistics. Oxford Bull. Economy. Stat., 54: 461- 472.

38. Mills, J. and K. Prasad, 1992. A comparison of model selection criteria. Economy. Rev., 11: 201233.

39. Maddala, G.S., 1992. Introduction to Econometrics. $2^{\text {nd }}$ Edn. Prentice Hall, New Jersey.

40. Levine, R. and D. Renelt, 1992. A sensitivity analysis of cross-country regressions. American economy. Rev., 82: 942-963. 